\title{
From Demonstrative to Nominalizer: The Suffix -gai in Northern Tepehuan $^{1}$
}

\author{
STEFANIE RAMOS BIERGE \\ University of Colorado, Boulder
}

\section{Introduction}

Nominalization is an area of morphosyntax which has attracted interest in recent years as data from an increasing number of languages have become available. Comrie and Thompson (2007:334) define nominalization as the process of "turning something into a noun". The same scholars propose that two types of nominalization can be found across languages: (i) lexical and (ii) clausal. The former refers to the creation of lexical nouns from verbs or adjectives and the latter to turning a complete clause into a noun phrase.

Linguistic studies have focused on the description of different types of nominalization and the means for creating them. However, what is known about the sources of nominalizing morphemes is still limited.

In this paper, I examine clause nominalization in Northern Tepehuan (NT hereinafter), particularly the source of the nominalizer -gai that occurs in complement and adverbial clauses. I propose that this suffix originates from the demonstrative igai, which also functions as $3 \mathrm{SG} / \mathrm{PL}$ pronoun. Evidence comes from the examination of word order in clauses when this demonstrative acts as a personal pronoun, which led to the reanalysis of this element into a suffix. I test the hypothesis by also showing a similar path of grammaticalization with the suffix - go. The data from NT used in this paper comes from my own fieldwork as well as from Bascom (1982) and Rinaldini (1994). Data from Pima Bajo (Hale 2002; Estrada, In Press) is used as well.

\footnotetext{
1 I am very thankful to Araceli Carrillo Carrillo, a Northern-Tepehuan speaker, for teaching me her language and helping me to develop this research. I am also thankful to Dr. Erin Shay for her interesting commentaries and to the National Council for Science and Technology (CONACyT) and the Center for the Study of Indigenous Language of the West (CSILW) for their financial aid.
} 


\section{Stefanie Ramos Bierge}

This paper is structured as follows. Section 1 provides a very brief typological description of NT. Section 2 describes lexical and clausal nominalization in NT and other Uto-Aztecan languages spoken in Mexico. Section 3 shows the path of grammaticalization of the suffix -gai in NT, and section 4 summarizes the conclusions.

\section{Grammatical Aspects of NT}

NT, a language pertaining to the Tepiman branch of the Uto-Aztecan family (Dakin 2004), is spoken in the southern area of Chihuahua, Mexico. There are currently three recognized dialects, which are located in the regions of Nabogame, El Venadito, and Baborigame. The dialect from the latter region is described in this paper, particularly from 'El Túpure'.

NT is characterized typologically as an agglutinative and head-marking language with a nominative-accusative case system. The language lacks morphological case markers in nouns; however, its nominative-accusative nature is manifested through two sets of pronouns, namely, subjects and non-subjects as it is shown in Table (1).

Table (1). Pronominal paradigm in NT.

\begin{tabular}{|l|l|l|l|l|l|l|}
\hline Person & $\begin{array}{l}\text { Subject } \\
\text { pronouns }\end{array}$ & $\begin{array}{l}\text { Non-subject } \\
\text { pronouns }\end{array}$ & $\begin{array}{l}\text { Pronominal } \\
\text { clitics }\end{array}$ & $\begin{array}{l}\text { Reflexive } \\
\text { pronouns }\end{array}$ & $\begin{array}{l}\text { Possesive } \\
\text { pronouns }\end{array}$ & $\begin{array}{l}\text { Ponouns in } \\
\text { posposition }\end{array}$ \\
\hline 1SG & aani & gin- & $=$ ni & gin- & gin- & gin- \\
\hline 2SG & aapi & gi- & $=$ pi & gi- & gi- & gi- \\
\hline 3SG & igai & $\varnothing$ & $\varnothing$ & gi- & -di & $\varnothing$ \\
\hline 1PL & $\begin{array}{l}\text { aatimi } ~ \\
\text { aatini }\end{array}$ & gir- & $\begin{array}{l}\text { =ir } \\
\text { =tini }\end{array}$ & gir- & gir- & gir- \\
\hline 2PL & aapimu & gin- & =pimu & gin- & gin- & gin- \\
\hline 3PL & igai & $\varnothing$ & $\varnothing$ & gin- & -di & $\varnothing$ \\
\hline $\begin{array}{l}\text { Non- } \\
\text { specific }\end{array}$ & $\varnothing$ & ga- & $\varnothing$ & $\varnothing$ & $\begin{array}{l}\text {-ga (objects \& } \\
\text { animals })\end{array}$ & $\varnothing$ \\
\hline
\end{tabular}

The use of this set of pronouns is illustrated in the examples below. The subject of an intransitive clause as well as an agent of a transitive clause is encoded by independent subject pronouns like the subject aapimu '2PL.SBJ' in (1a) and the agent igai '3SG.SBJ' in (1b). The patient, on the contrary, takes a nonsubject pronoun that prefixes into the verb, like gir- '1 PL.NSBJ' in (1b).

NT has a primary object system manifested by the marking of recipients or 
beneficiaries with non-subject prefixes in ditransitive clauses. This is exemplified in (1b) and (1c) where the non-subject pronoun gir- '1PL.NSBJ' marks a recipient argument in the latter while in the former the same non-subject pronoun is used to encode a patient.
a. aapimu kokoso.
2PL.SBJ sleep.PRS
'You sleep.'2
b. igai gir-gigi.
3SG.SBJ 1PL.NSBJ-hit.PFV
'He hit us.'
c. igai gir-ootosi tuminsi.
3SG.SBJ 1PL.NSBJ-send.PFV money
'He sent us money.'

A simple clause in NT is normally constituted by a verb and a noun phrase or pronoun. In the intransitive clauses, the unmarked word order is SV as in (2a), while in a transitive clause is AVP as in (2b). However, word order may be relatively free (Cf. Bascom 1982).

(2) a. gwana suaka-i.

John cry-PRS

'John cries.'

b. maria guikoma yoosigai.

Mary cut.PFV flower.PL

'Mary cut flowers.'

\section{$2 \quad$ Nominalization in NT}

\subsection{Lexical nominalization}

NT has three main derivational suffixes that create lexical nouns out of verbs: -kami, -dami, and -gami. The items derived with these suffixes act syntactically as

\footnotetext{
2 Abbreviations: $1=$ first; $2=$ second, $3=$ third; $A P P L=$ applicative; $\quad \mathrm{CONJ}=$ conjunction; CONT=continuous $; \quad$ CONTI $=$ continuative $; \quad \mathrm{COP}=$ copula $; \quad \mathrm{DET}=$ determiner $; \quad \mathrm{DEM}=$ demonstrative; $\mathrm{DIR}=$ directional; $\mathrm{DUB}=$ dubitative; $\mathrm{FUT}=$ future; INSTR=instrumental; INT=intensive; IRR= irrealis; LIN=linker; $\quad$ LOC=locative; $\quad \mathrm{NMLZ}=$ nominalization; $\quad \mathrm{NSBJ}=$ non-subject; $\quad$ PART=particle; $\mathrm{PFV}=$ perfective; $\quad \mathrm{PL}=$ plural; $\quad \mathrm{POS}=$ possessive; $\quad \mathrm{PROB}=$ probable; $\quad \mathrm{PRS}=$ present; $\quad \mathrm{PST}=$ past; $\mathrm{QUOT}=$ quotative; $\mathrm{REL}=$ relativizer; $\mathrm{RDP}=$ reduplication; $\mathrm{SBJ}=$ subject; $\mathrm{SBR}=$ subordinator; $\mathrm{SG}=$ singular; $\mathrm{ST}=$ stative; $\mathrm{VR}=$ verbalizer.
} 


\section{Stefanie Ramos Bierge}

nouns since they can appear with the determiner go, can be reduplicated to indicate plural, and act as arguments of verbs. Examples with -dami are shown in (6), with -kami in (7), and with -gami in (8). ${ }^{3}$
(6) oha-dami mi=nia-dami duduad ${ }^{\mathrm{y}} \mathrm{a}-\mathrm{dami}$ duu-ku-dami

write-NMLZ NEG=see-NMLZ heal-NMLZ rain-ku-NMLZ
'teacher.' 'blind.' 'healer.' 'thunder.'

$\begin{array}{llll}\text { maati-kami } & \text { koko-kami } & \mathrm{mi}=\mathrm{d}^{\mathrm{y}} \mathrm{u}-\mathbf{k a m i} & \mathrm{mi}=\text { k̈̈i-kami } \\ \text { know-NMLZ } & \text { get_sick-NMLZ } & \mathrm{NEG}=\mathrm{d}^{\mathrm{y}} \mathrm{u}-\mathrm{NMLZ} & \mathrm{NEG}=\text { hear-NMLZ } \\ \text { 'soothsayer.' } & \text { 'sick.' } & \text { 'orphan.' } & \text { 'deaf.' }\end{array}$
(8) tuminsi-gami soiti-gami duad ${ }^{y}$ i-gami money-NMLZ soiti-NMLZ heal-NMLZ 'rich.' 'poor.' 'remedy.'

The suffix -kami is also attested in the formation of adjectives that function as attributives when they follow the noun they modify. Bascom (1982:298) shows examples where -gami is used for the same purpose as in (10).

(9) biigi-kami

red-NMLZ

'something that is red.'

\section{yosia-kami}

flower-NMLZ

'something that is flowered.'

$\begin{array}{ll}\text { igo-kami } & \text { tibidu-kami } \\ \text { sour-NMLZ } & \text { get_tired-NMLZ } \\ \text { 'sour.' } & \text { 'tired.' }\end{array}$

(10) pari-gami

omali-gami

lazy-NMLZ bad-NMLZ

'lazy person.' 'bad person.'

Another nominalizer that has been attested in the language is -karo 'INSTR', which creates nouns out of verbs as in (11). In very few cases, -gai 'NMLZ' is also found as in (12).

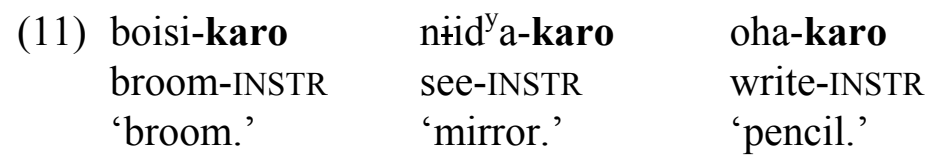

3 See Bascom (1982:297) for an explanation on their differences. 
(12) kuagai 'eat.PRS' > kuada-gai 'food, what is eaten.' gaatadui 'work.PFV' > aduind"a-gai 'job, what is worked.' toñi 'hot.' $\quad>\quad$ toind ${ }^{\mathrm{y}}$ a-gai 'have fever.'

\subsection{Clausal nominalization in NT}

Before describing the way this language nominalizes clauses, I will first describe the behavior of verbal finite clauses to observe the differences.

The agglutinative nature of the language allows the identification of some of the morphemes that encode finite events: $-i$ 'PRS', -tadai 'PST.CONT', $-m u$ 'FUT.PROB', -to 'PFV'. Some of them are illustrated in (13) and (14). The participants of the event are expressed as noun phrases or pronouns that either precede or follow the verb. As mentioned in section 1, NT marks case only with non-subject pronouns attached to the verb.

(13) gwana mira-i.

John run-PRS

'John runs.'

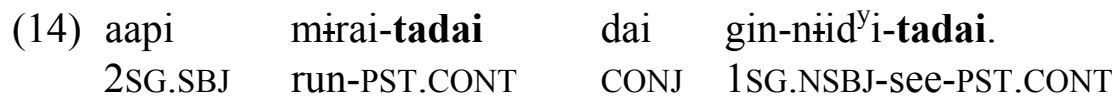

'You were running and looking at me.'

Other verbs do not have tense or aspect morphemes attached to them. Instead, they present a non-marked form that encodes present tense as in (15). Some others undergo reduplication to indicate aspectual events as in (16) or suppletion to indicate number as in (17).

(15) aani koso.

1SG.SBJ sleep.PRS

'I sleep.'

(16) maria ka kaisi-i

radio.

Mary RDP.CONTI listen-PRS radio

'Mary listens to the radio.'

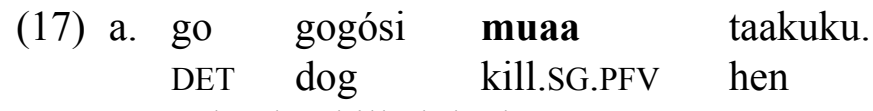

'The dog killed the hen.' 


\section{Stefanie Ramos Bierge}

$\begin{array}{llrl}\text { b. go gógosi } & \text { kooda } & \text { tatako. } \\ \text { DET } & \text { dog.PL } & \text { kill.PL.PFV } & \text { hen.PL }\end{array}$

'The dogs killed the hens.'

Clausal nominalization in NT occurs in subordination with complement or adverbial clauses in which one clause or event is dependent of the other in semantic and morphosyntactic terms. In this sense, the clause loses tense-aspect morphology, -gai 'NMLZ' is attached to the verb, and in few cases the determiner go is included. Although NT is not isolating in nature, few morphosyntactic characteristics are found. According to Koptjevskaja-Tamn (1993:88), this degree of analyticity favors clausal nominalization. Some examples are shown in (18) with object complement clauses and in (19) with adverbial clauses. In (18a), the verb tihai 'order' takes a subordinate clause indicated by $i s=$ 'SBR'. The verb of the dependent clause is modified by the suffix -gai. In (18b), the verb imii 'walk' has the suffix -gai and is still modified by the adverb kaban 'a lot'. A similar situation is illustrated in (19) with the adverbial clauses in which oogisda 'forgive' and bagai 'to water' present the suffix -gai.

(18) a. ruisi tihai mara-di is $=$ nïd ${ }^{\mathrm{y}} \mathrm{a}-\mathrm{gai} \quad$ urid $^{\mathrm{y}} \mathrm{i}$.

Luis order.PRS son-3SG.POS SBR $=$ see-NMLZ grandmother

'Luis ordered his son to visit her grandmother.'(Carrillo 2011:66) ${ }^{4}$

b. galtada $=$ ni kaban imii-gai.

regret $=1 \mathrm{SG}$ a_lot walk-NMLZ

'I regret walking a lot.'

(19) a. buana ootosi yoosigai maria is=oogisd ${ }^{\mathrm{y}} \mathrm{a}-$ gai.

John send.PRS flower Mary SBR=forgive-NMLZ

'John sends flowers to Maria so that she forgives him.'

b. sikia=ni baga-gai yosigai kaban gili-mo-go.

$\mathrm{SBR}=1 \mathrm{SG}$ water-NMLZ flower a_lot grow-FUT.PROB-NMLZ

'When I water the plants, they will grow up a lot.'

Verbs in the nominalized clause preserve their arguments as it is shown in (20) and (21) where muaa 'to kill' takes the patient pipisuri 'chicken' and iyai 'drink' takes sudagi 'water', both encoded with noun phrases.

(20) galtadatua $=$ ni mua-gai go pi ppisuri.

regret=1SG kill-NMLZ DET RDP.PL $\sim$ chicken

'I regretted killing the chicken.'

4 Glosses of examples taken from other sources are changed from the original. 
From demonstrative to nominalizer: Suffix -gai in NT

(21) rupa ipilid ${ }^{\mathrm{y}}$ iya-gai sudagi.

Lupe think drink-NMLZ water

'Guadalupe decided to drink water.'

More evidence that shows that this is clausal nominalization is illustrated in (22) in which the nominalized verb ipilitgai can still take a dependent clause with the subordinator $i s=$.

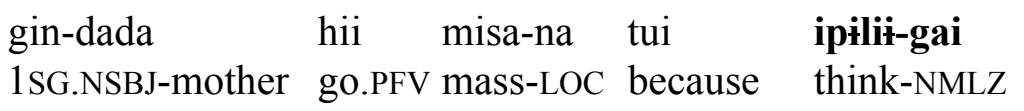

is $=$ ma $\sim$ matul-d ${ }^{\mathbf{y}} \mathbf{a} \quad$ mara-di.

$\mathrm{SBR}=\mathrm{RDP} \sim$ pray-APPL son-3SG.POS

'My mother went to mass because she wanted to pray for his son.'

Subject complement clauses in NT present nominalized clauses as well. However, I consider that they are in a more advanced degree of nominalization because the clause can be possessed or the determiner go can be used, but both are still optional as examples (23) and (24) illustrate.

(23) (go) pasaria-gai chiguaguama-ko ki=baitada-tu.

DET travel-NMLZ Chihuahua-DIR good=feel_well-PFV

'The trip to Chihuahua was good.'

(24) (gin-)imiya-gai hermosiyi-ri ir ibimuda-gai.

1SG.NSBJ-go-NMLZ Hermosillo-LOC COP get_tired-NMLZ

'Going to Hermosillo was tiring.'

Bascom (1982:295-7) in his grammatical sketch describes that there are a series of morphemes that derive lexical nouns from verbs such as -gai, -dagai, and -ragai. The last two result from the combination of $-d a$ 'VR' $+-g a i$ and $-r a+$ $-g a i^{5}$. Only in one case, the suffix -dagai seems to serve the function of a lexical derivational morpheme as in aduind'agai 'job'. Nonetheless, in the other examples that he provides, I consider them as having the function of clausal nominalizers as illustrated in (25) with an adverbial clause in which the nominalized verb is still negated, and in (26) with a complement clause in which the nominalized verb ivaragai follows the finite verb maatigi.

$5 \quad$ Bascom (1982) does not provide the meaning of the suffix -ra. 


\section{Stefanie Ramos Bierge}

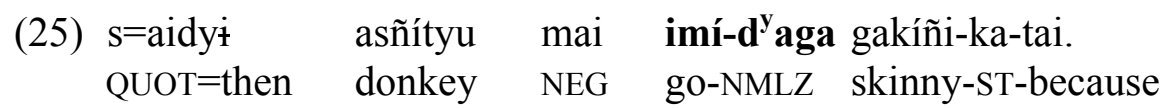

'And the donkey does not go fast, because he's skinny.'

(26) maati-gi iva-ragai aliisi amaityi tuminsi.

know-IRR play-NMLZ very.INT earn money

'If he knew how to play an instrument, he'd really make money.'

Bascom and Molina (1998) even provide lexical entries of verbs with the suffix -gai with meanings such as 'what is V' like xikuanaragai 'what is plowed' or kïdaragai 'withcraft, to witchcraft, what is witchcrafted', which gives the sense of clausal nominalizations.

\subsubsection{Clausal nominalization in other Uto-Aztecan languages}

Some Uto-Aztecan languages nominalize clauses by using a suffix that creates lexical nominalizations. Such languages are Yaqui (Guerrero 2005), Tarahumara (Burguess 1984), Pima Bajo (Estrada 2010), Ópata (Ramírez 2010), Warijio (Felix 2005), and Nevome (Shaul 1982; Villalpando 2009). The strategies used by these languages are summarized in Table (2).

Table (2). Nominalizing suffixes in Uto-Aztecan languages.

\begin{tabular}{|c|c|c|c|}
\hline Language & $\begin{array}{l}\text { Nominalizing } \\
\text { suffix }\end{array}$ & Clause type & Characteristics \\
\hline $\begin{array}{l}\text { Yaqui } \\
\text { (Guerrero 2005) }\end{array}$ & $\begin{array}{l}-m e \\
-u\end{array}$ & $\begin{array}{l}\text { Relative and } \\
\text { Complement }\end{array}$ & $\begin{array}{l}-m e \text { is the preferred suffix to } \\
\text { derive lexical nouns. }\end{array}$ \\
\hline $\begin{array}{l}\text { Tarahumara } \\
\text { (Burguess 1984) }\end{array}$ & -ame $\sim-m e$ & $\begin{array}{l}\text { Relative and } \\
\text { adverbial }\end{array}$ & $\begin{array}{l}-m e \text { is also used to derive } \\
\text { lexical nouns. }\end{array}$ \\
\hline $\begin{array}{l}\text { Pima Bajo } \\
\text { (Estrada 2010) }\end{array}$ & $-d a m$ & $\begin{array}{l}\text { Relative and } \\
\text { adverbial }\end{array}$ & $\begin{array}{l}\text {-dam is used to create } \\
\text { lexical nouns. }\end{array}$ \\
\hline $\begin{array}{l}\text { Ópata } \\
\text { (Ramírez 2010) }\end{array}$ & $\begin{array}{l}\text {-ca, -came } \\
\text {-mui and -sari }\end{array}$ & $\begin{array}{l}\text { Relative and } \\
\text { complement }\end{array}$ & $\begin{array}{l}\text {-mui and -sari create lexical } \\
\text { nouns. } \\
-c a \text { or -came nominalize } \\
\text { clauses. }\end{array}$ \\
\hline $\begin{array}{l}\text { Warijio } \\
\text { (Felix 2005) }\end{array}$ & -(a)me & $\begin{array}{l}\text { Relative, } \\
\text { complement, } \\
\text { and adverbial }\end{array}$ & $\begin{array}{l}\text {-(a)me also derives lexical } \\
\text { nouns. }\end{array}$ \\
\hline $\begin{array}{l}\text { Nevome } \\
\text { (Shaul 1982; Villalpando } \\
\text { 2009) }\end{array}$ & $\begin{array}{l}\text {-cama } \\
\text {-cugai }\end{array}$ & $\begin{array}{l}\text {-cama: } \\
\text { Relative } \\
\text {-cugai: } \\
\text { Complement, } \\
\text { Adverbial }\end{array}$ & $\begin{array}{ll}\text {-dama, -cama, -parha, } \\
\text {-daga: derive lexical nouns. } \\
\text {-cama and -cugai } \\
\text { nominalize clauses. }\end{array}$ \\
\hline
\end{tabular}


From demonstrative to nominalizer: Suffix -gai in NT

\section{Path of grammaticalization of the suffix -gai in NT}

Section 2.2.1 shows that most of the Uto-Aztecan languages spoken in Mexico, namely Yaqui, Pima Bajo, Ópata, Nevome, Tarahumara, and Warijio tend to nominalize clauses with the same suffix that derives lexical nominalizations. Bascom (1982:379) provides some examples from NT in which the suffix -kami is suffixed to a relative clause as in (27). Nonetheless, in recent data, NT does not generally use the suffixes -kami, -dami, or -gami for clausal nominalization. Instead, the suffix -gai occurs in complement and adverbial clauses. In relative clauses, verbs tend to be finite as in (28) with the verb nityi 'sing.PRS'.

(27) maati $=\mathrm{mi}$ aapimi uurugi gii kii-iri odi ${ }^{\mathrm{y}} \mathrm{a}-\mathrm{kami}$.

know=2PL 2PL.SBJ bird big house-LOC live-NMLZ

'You know the bird that lives in the big house.' (Bascom 1982:379)

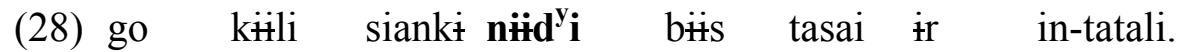
DET man SBR sing.PRS all sun COP 1SG.NSBJ-uncle 'The man who sings everyday is my uncle.'

Nevome (Villalpando 2009) is the only language that shares a cognate suffix -cugai with NT for nominalizing clauses.

By looking at Nevome and NT and the difference in clausal nominalizing patterns from other Uto-Aztecan languages, a question arises: What is the source of this suffix? My hypothesis is that the possible source of this item is the demonstrative igai. The idea that a nominalizer may come from a demonstrative or determiner is attested (LaPolla 2006; Simpson 2008). Therefore, the propose path of grammaticalization for NT is the following: igai: 'DEM'>3SG/PL $>-g a i$ 'NMLZ'. Grammaticalization in this paper is understood as the process whereby lexical items in certain contexts become more grammatical or a grammatical item becomes even more grammatical. But this process is seen as gradual so that transitions lead sometimes to coexistence of elements or overlaps (Lehmann 1988; Heine et al. 1993; Heine and Kuteva 2002; Hopper and Traugott 2003).

The demonstrative igai generally denotes distant location from the point of view of the speaker and always precedes the noun. See examples (29) and (30).

(29) igai ir go küli.

DEM COP DET man

'That is the man.'

(30) tumaasi id ${ }^{\mathrm{y}} \mathrm{i}$ igai.

what this DEM

'What is it?' (Bascom 1982:391) 


\section{Stefanie Ramos Bierge}

The demonstrative igai also serves the function of $3 \mathrm{SG} / \mathrm{PL}$ pronoun when the speaker refers to a human entity as it is shown in examples (31) and (32). In this function, it can precede or follow the verb as the other personal pronouns in the language.

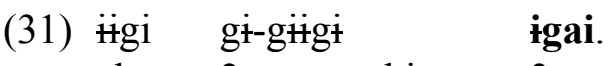

alone 2SG.NSBJ-hit.PFV 3SG.SBJ

'He hit himself.' (Bascom 1982:274)

(32) igai

$\begin{array}{lll} & \text { gin-botibi-i } & \text { suudia-na. } \\ \text { 3PL.SBJ 1PL.NSBJ-swim-PRS } & \text { agua-LOC } \\ \text { 'They swim in the water.' } & \end{array}$

This free word order may have been the cause for the reanalysis of the demonstrative as a suffix for nominalization in subordinate clauses. To test this hypothesis, I will briefly explain the behavior of participants in dependent clauses in the following paragraphs.

In a few complement clauses, the patient participant of the verb is placed within the main clause, that is, before the subordinator, especially if a proper name is used. In this case, igai occurs in the dependent clause with a coreferential function. This is illustrated in (33).

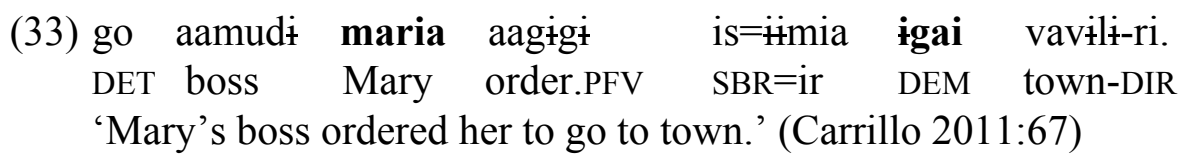

Probably, the use of igai as a strategy for indicating co-referential participants was common. Generally, in complement clauses where personal pronouns are used, a subject clitic is attached to the verb in the subordinate clause with a coreferential function as in (34). Nonetheless, additional data show that although a sentence has a proper name, only the suffix -gai occurs and not the demonstrative tgai as in (35) and (36).
gi-agihia $=n \dot{i}$
$2 \mathrm{SG} . \mathrm{NSBJ}-\mathrm{say}=1 \mathrm{SG}$
is $=$ gin-gagald
$\mathrm{SBR}=1 \mathrm{a}=\mathbf{p i}$
SG.NSBJ-sell $=2 \mathrm{SG}$
go kabayo.
'I asked you to sell the horse to me.'

(35) aapi niid ${ }^{\mathrm{y} a-g i}$ gwana is=imi-gai.

2SG.SBJ see-IRR John SBR=walk-NMLZ

'You will see John walk.' 
(36) aapi titidai maria is=imia-gai.

2SG.SBJ say.PFV Mary SBR $=$ go-NMLZ

'You asked Mary to go.'

The complete grammaticalized stage of the demonstrative is shown in examples (37) in which although there are only personal pronouns, the suffix -gai still manifests itself. ${ }^{6}$
(37) aani baiga is=aata-gai.
1SG.SBJ can SBR=tell-NMLZ
'I can speak.'

Another path of grammaticalization that is worth mentioning is a possible nominalizer that is emerging in NT and that has been attested in only a few cases: -go. It seems that this suffix is following a similar path: gobai 'distant DEM'>go DET $>3 \mathrm{SG} / \mathrm{PL}>-$ go 'NMLZ'. Example (38) illustrates gobai as 3SG/3PL, (39) the use of $g o$ as DET, and (40) - $g o$ as nominalizer in a complement clause.

(38) a. gobai biskiri gin-tani-i taskali. 3PL.SBJ always 1SG.NSBJ-ask_for.PRS tortilla 'They always ask me for tortillas.'

b. $\varnothing=$ si=iis-kidi imi-mu goo. he=DUB=how_much-with go-FUT.PROB he 'When will he go.' (Bascom 1982:292)

(39) a. go gogosi

DET dog

'The dog.'

b. baityoma mai maati-mu goo(bai) aana iñ =ilidi. almost NEG know-FUT.PROB DEM 1SG.SBJ I=think 'I think you are probably not going to know (guess that).' (Bascom 1982:390)

(40) a. gwana agihi maria is=sabida-go go kabayo. John say.PFV María SBR=buy-NMLZ DET horse 'John told Mary to buy a horse.'

\footnotetext{
6 Sometimes, when a proper name is used, there is no suffix -gai but research still needs to be done. This paper will not describe it.
} 


\section{Stefanie Ramos Bierge}
b. id $d^{\mathrm{y}} u \mathrm{i}-\mathrm{ñi}$
is $=\mathrm{d}^{\mathrm{y}}$ ibia-go
gi-kii-yi-rí.
make.PFV-1SG.SBJ
$\mathrm{SBR}=$ come.PFV 2SG.NSBJ-house-POS-DIR
'I made him come to your house.' (Carrillo 2011:68)

In fact, in (40a) it can be observed that -go and go coexist in the same environment, which means that they have different functions in the same clause.

More evidence about the possible path of grammaticalization of the suffix -gai is observed in the Arte de la Lengua Tepeguana written by Rinaldini (1994:7). He said that uggue 'demonstrative' was used as a 'relativizer' along with the particle $n a$ as in (41). By looking at the example that he provides, it seems that cugge is acting as the nominalizer of the verb jimoe 'come' in this relative clause.
(41) iddi na ia jimoe-cugge.
DEM PART close come-DEM
'this who come close.'

Finally, the last evidence is observed in Pima Bajo. According to Hale (2002) and Estrada (In Press), this language has a relative clause marker -kig shown in (42). Both scholars state that this may have originated from the demonstrative higam + the stative $-k a$. Moreover, Estrada (In Press) mentions that this relative clause marker is evolving into a clause linker because it also appears not directly attached into the verb but into the oblique noun or postpositional phrase as it is illustrated in (43). Although NT shows a similar path of grammaticalization as the one proposed by these scholars, it seems that the suffix in NT developed a different function in complex constructions.

(42) huaan hig am dah-kig.

John 3SG.SBJ LOC be_sit.SG.PFV-REL

'John is the one that is sitting there.'

(43) aan ko'ag taatar tiipar-ta-kig aap in=hivga-di.

1SG.SBJ firewood cut.PFV ax-ta-LIN 2SG.SBJ 1sG.NSBJ=lend-APPL

'I cut the firewood with the ax you lend me.

\section{Conclusions}

In this paper, I described and analyzed clausal nominalization patterns in NT as well as in other Uto-Aztecan languages spoken in Mexico. All of them present suffixes that create nouns out of verbs, i.e. they serve the function of lexical nominalizers. The same particles nominalize clauses in all these languages except for NT. Instead, NT has a suffix -gai that mainly appears in complement and adverbial clauses. In this paper, I proposed that the possible source of this suffix is the demonstrative igai. This hypothesis was tested by illustrating that when the 
From demonstrative to nominalizer: Suffix -gai in NT

demonstrative serves the function of 3SG/PL pronoun, it behaves as the other personal pronouns by preceding or following the main or subordinate verb. The fact that this demonstrative in dependent clauses has a co-referential function in a few cases may have caused the reanalysis of this item, and therefore, turned it into a nominalizing suffix. More evidence that proves this hypothesis is the presence of the suffix -go as well as NT data from Rinaldini (1994) and data from Pima Bajo (Hale 2002; Estrada, In Press).

\section{References}

Bascom, Burton.W. 1982. Northern Tepehuan. In R. W. Langacker, ed., Studies in Uto-Aztecan Grammar. Uto-Aztecan Grammatical Sketches, 3:267-393, Dallas: Summer Institute of Linguistics/ University of Texas at Arlington.

Bascom, B.W. and G. Molina. 1998. Diccionario Tepehuán de Baborigame, Ms., Chihuahua: Instituto Lingüístico de Verano.

Burgess, Donald H. 1984. Western Tarahumara. In R.W. Langacker, ed., Studies in Uto-Aztecan Grammar. Southern Uto-Aztecan Grammatical Sketches, 4:1149, Dallas, TX: The Summer Institute of Linguistics and The University of Texas at Arlington.

Carrillo Carrillo, Araceli. 2011. Construcciones Causativas en Odami o Tepehuano del Norte. B.A. thesis, Hermosillo: Universidad de Sonora.

Comrie, B. and S.A. Thompson. 2007. Lexical Nominalization. In T. Shopen, ed., Language Typology and Syntactic Description: Grammatical Categories and Lexicon, 3: 349-348, Cambridge: Cambridge University Press.

Dakin, Karen. 2004. Prólogo. In Z. Estrada Fernández et al. Diccionario yaquiespañol y textos. Obra de preservación lingüistica, 13-20, México: Editorial Plaza Valdés/Universidad de Sonora.

Estrada Fernandez, Z. In Press. From Demonstrative to a Relative Marker to Clause Linker: The Relative Clause Formation in Pima Bajo. In Z. Estrada Fernandez and B. Comrie, eds., A Typological Overview of Relative Clauses in Languages of the Americas, Amsterdam: John Benjamins Publishing.

Félix Armendáriz, Rolando. Gpe. 2005. A Grammar of River Warihío. PhD thesis, Houston: Rice University.

Guerrero, Lilián. 2005. Yaqui Relative Clauses. In J. Harper and L. Harper, eds., 
Stefanie Ramos Bierge

Proceedings from the Eighth Workshop on American Indigenous Languages, 16:15-27, Santa Barbara Papers in Linguistics. The University of California. Santa Barbara.

Hale, Kenneth L. 2002. On the Dagur Object Relative: Some Comparative Notes. Journal of East Asian Linguistics, 11:109-122.

Heine, Bernd. 1993 [1991]. Auxiliaries. Cognitive Forces and Grammaticalization. New York: Oxford University Press.

Heine, B. and T. Kuteva. 2002. World Lexicon of Grammaticalization. Cambridge: Cambridge University Press.

Hopper, P.J. and E.C. Traugott. 2003. Grammaticalization. 2nd edition. Cambrige: Cambridge University Press.

Kopstjevskaja-Tamm, Maria. 1993. Nominalizations. London/New York: Routledge.

LaPolla, Randy J. 2006. Nominalization in Rawang. Invited keynote address presented at the $39^{\text {th }}$ International Conference on Sino-Tibetan Languages and Linguistics. University of Washington, Seattle, September.

Lehmann, Chistian. 1988. Towards a Typology of Clause Linkage. In J. Haiman and S.A. Thompson, eds., Clause Combining and Grammar Discourse. Amsterdam/Philadelphia: John Benjamins Publishing Company.

Ramírez Mendívil, Moises. 2010. Nominalización en Ópata. M.A. thesis, Hermosillo: Universidad de Sonora.

Rinaldini, Benito. 1994 [1743]. Arte de la Lengua Tepeguana. Con Vocabulario, Confessionario y Catecismo. Durango: Consejo Nacional para la Cultura y las Artes. Gobierno del estado de Durango.

Simpson, Andrew. 2008. The Grammaticalization of Clausal Nominalizers in Burmese. In M.J. López-Couso and E. Seoanne, eds., Rethinking Grammaticalization. New Perspectives, 265-288, Amsterdam/Philadelphia: John Benjamins Publishing Company.

Shaul, David .L. 1982. A Grammar of Nevome. PhD thesis, University of California, Berkeley. 
Villalpando Quiñónez, Jesús. 2009. Pertenecé á el Pueblo del Pitic: Un Análisis de las Estrategias de Combinación de Cláusulas Complejas en el Arte de la Lengua Névome (yutoaztecas; tepimana). B.A. Thesis, Hermosillo: Universidad de Sonora.

\author{
Stefanie Ramos Bierge \\ University of Colorado, Boulder \\ Department of Linguistics \\ Hellems 290, 295 UCB \\ Boulder, CO 80309-0295 \\ stefanie.ramosbierge@colorado.edu \\ stef_bierge@yahoo.com.mx
}

